\title{
Efficient production of methane from artificial garbage waste by a cylindrical bioelectrochemical reactor containing carbon fiber textiles
}

\author{
Daisuke Sasaki ${ }^{1,3}, K^{2}$ gengo Sasaki ${ }^{2,3}$, Atsushi Watanabe ${ }^{1}$, Masahiko Morita ${ }^{1 *}$, Yasuo Igarashi ${ }^{2}$ and Naoya Ohmura ${ }^{1}$
}

\begin{abstract}
A cylindrical bioelectrochemical reactor (BER) containing carbon fiber textiles (CFT; BER + CFT) has characteristics of bioelectrochemical and packed-bed systems. In this study, utility of a cylindrical BER + CFT for degradation of a garbage slurry and recovery of biogas was investigated by applying $10 \%$ dog food slurry. The working electrode potential was electrochemically regulated at $-0.8 \mathrm{~V}$ (vs. Ag/AgCl). Stable methane production of $9.37 \mathrm{~L}-\mathrm{CH}_{4} \cdot \mathrm{L}^{-1}$. day $^{-1}$ and dichromate chemical oxygen demand (CODcr) removal of $62.5 \%$ were observed, even at a high organic loading rate $(\mathrm{OLR})$ of $89.3 \mathrm{~g}-\mathrm{CODCr} \cdot \mathrm{L}^{-1} \cdot \mathrm{day}^{-1}$. Given energy as methane $\left(372.6 \mathrm{~kJ} \cdot \mathrm{L}^{-1} \cdot\right.$ day $\left.^{-1}\right)$ was much higher than input electric energy to the working electrode $\left(0.6 \mathrm{~kJ} \cdot \mathrm{L}^{-1} \cdot\right.$ day $\left.{ }^{-1}\right)$ at this OLR. Methanogens were highly retained in CFT by direct attachment to the cathodic working electrodes $(52.3 \%$; ratio of methanogens to prokaryotes), compared with the suspended fraction (31.2\%), probably contributing to the acceleration of organic material degradation and removal of organic acids. These results provide insight into the application of cylindrical $\mathrm{BER}+\mathrm{CFT}$ in efficient methane production from garbage waste including a high percentage of solid fraction.
\end{abstract}

Keywords: Bioelectrochemical reactor, Supporting material, Carbon fiber textile, Thermophilic methanogenesis, High organic loading rate

\section{Introduction}

Recycling of the huge organic fraction in municipal solid wastes such as garbage and waste from the food industry has been long-awaited (Haruta et al. 2005). Anaerobic digestion using methane fermentation is an effective technology for recovering methane gas as a renewable energy source. It is a low-cost process and produces little residual sludge (Ahring 2003; Forster-Carneiro et al. 2008). Various processes have been exploited to increase the efficiency of methane fermentation. Thermophilic packed-bed systems have been reported to be one of the high-performance reactor designs (Sasaki et al. 2007; Ueno et al. 2007). In the packed-bed system, supporting materials were packed to retain microorganisms and thereby enable operation at a high organic loading rate (OLR) and short hydraulic retention time (HRT; Sasaki

\footnotetext{
* Correspondence: masahiko@criepi.denken.or.jp

'Biotechnology Sector, Environmental Science Research Laboratory, Central Research Institute of Electric Power Industry, 1646 Abiko, Abiko-shi, Chiba-ken 270-1194, Japan

Full list of author information is available at the end of the article
}

et al. 2010a). In our previous study, carbon fiber textiles (CFT) that have surface hydrophobicity and porous structure for better retention of microorganisms were used as supporting materials (Sasaki et al. 2010a).

Previous research has found that a bioelectrochemical reactor (BER) can stimulate microbial metabolism and affect the growth rate of microorganisms by controlling the electron flow in the culture medium (Thrash et al. 2007; Matsumoto et al. 2002). Recently, a BER was used for methane fermentation to stabilize methane production at a high OLR and to shorten the startup period by accelerating microbial growth (Sasaki et al. 2010b, 2011a). In addition, a BER containing CFT (BER + CFT) was exploited to have characteristics of a packed-bed and bioelectrochemical systems (Sasaki et al. 2011b). By introducing the electrochemical system to the methanogenic reactor, the BER + CFT (250-mL working volume) attained stable methane production at an OLR of 27.8 g-dichromate chemical oxygen demand $(\mathrm{CODcr}) \cdot \mathrm{L}^{-1} \cdot$ day $^{-1}$, using a substrate that mainly contained an artificial garbage slurry (AGS). In addition, 
effect of electrochemical regulation in BER + CFT was clarified by comparing BER + CFT with non-BER + CFT (without electrochemical regulation) (Sasaki et al. 2011b).

A scaled-up BER + CFT (2.4-L working volume) was operated at laboratory scale using a cylindrical type of reactor to apply BER + CFT to the usual methane fermentation system because the cylindrical type of reactor is utilized in anaerobic digestion (Angenent et al. 2002; Tatara et al. 2008). The cylindrical type of BER + CFT has a specific configuration in which the working chamber surrounds the counter chamber, and those 2 chambers are separated by a proton exchange membrane. Sewage sludge was applied to a cylindrical type of BER + CFT in our previous research and a scaled-up BER + CFT also showed the effect of electrochemical regulation (Sasaki et al. 2013). However, given that the concentration of organic matter in the sewage sludge was relatively low, high OLR operation was difficult. A garbage slurry including high percentage of solid fraction has not yet been applied to the cylindrical type of BER + CFT.

In the present study, the aim was to operate at high OLR conditions and investigate the reactor performance by using AGS (10\% dog food slurry) as a model of municipal solid waste and microbial community in the cylindrical type of BER + CFT. High OLR operation is important to demonstrate the potential for this technology in the efficient treatment of garbage slurry with a high percentage of solid content. Microbial communities on the working electrode and in the suspended fraction were quantitatively and qualitatively analyzed by 16S rRNA gene-based techniques such as real-time PCR assay and terminal restriction fragment length polymorphism (T-RFLP) analysis.

\section{Materials and methods \\ Feed material}

The AGS was prepared from $100 \mathrm{~g}$ of a commercial dog food (VitaOne, Nihon Pet Food, Tokyo, Japan) suspended in $1.0 \mathrm{~L}$ of sterilized water. The physicochemical characteristics of the AGS were as follows: total CODcr, $134.1 \mathrm{~g}-$ CODcr $\cdot \mathrm{L}^{-1}$; CODcr of supernatant, $8.4 \mathrm{~g}-\mathrm{CODcr} \cdot \mathrm{L}^{-1}$; suspended solid (SS), $54.0 \mathrm{~g} \cdot \mathrm{L}^{-1}$; and volatile suspended solid (VSS), $45.5 \mathrm{~g} \cdot \mathrm{L}^{-1}$.

\section{$\mathrm{BER}+\mathrm{CFT}$}

The BER + CFT was constructed from a glass vessel (4.0-L capacity) with several sampling ports and flow-line nozzles (Figure 1). The BER + CFT was separated into 2 chambers by a proton exchange membrane (Nafion N117, Dupont Co., Delaware, USA). CFT $(150 \times 164 \times 3 \mathrm{~mm})$ was adhered to the inside of a carbon plate $(150 \times 35 \times 6 \mathrm{~mm})$, and 8 carbon plates holding CFT were used to equip a cathodic working chamber (2.4-L working volume) as the cathodic working electrode and supporting material. To control the potential on the cathodic working electrode, an $\mathrm{Ag} / \mathrm{AgCl}$ reference electrode was inserted into the working chamber. The anodic counter chamber filled with $100-\mathrm{mM} \mathrm{NaCl}(180 \mathrm{~mL})$ was installed in the center of a reactor, and a columnar carbon bar (height $=150 \mathrm{~mm}$; radius $=4 \mathrm{~mm}$ ) was used as an anodic counter electrode.

Cathodic and anodic electrodes, and the reference electrode placed in the cathodic working chamber were connected to a potentiostat (PS-08, Tohogiken, Japan). Potential on the cathodic working electrode was regulated at $-0.8 \mathrm{~V}$ (vs. $\mathrm{Ag} / \mathrm{AgCl}$ ) because we previously reported that stable methane production and decomposition of garbage slurry at a high OLR were observed in a (a)

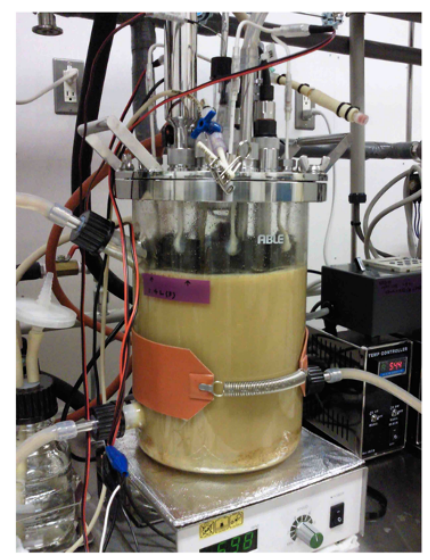

(b)

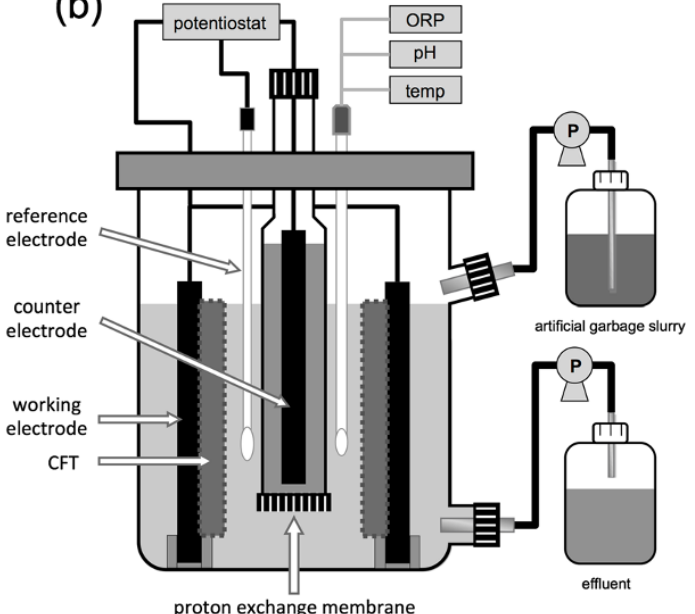

Figure 1 Photograph of the BER + CFT (a) and schematic diagrams of the BER + CFT (b). ORP: oxidation-reduction potential. 
small-scale thermophilic bioelectrochemical methanogenic reactor (250-mL working volume) regulated at $-0.8 \mathrm{~V}$ (Sasaki et al. 2010b). All the voltages reported in this paper are with respect to the $\mathrm{Ag} / \mathrm{AgCl}$ reference electrode (+201 mV vs. standard hydrogen electrode). The oxidationreduction potential was monitored, and $\mathrm{pH}$ and temperature were controlled by discrete control units (DJ-1023, DJ-10083, and DJ-1073; ABLE, Tokyo, Japan).

\section{Operation of the BER + CFT}

Seed sludge was collected from a packed-bed thermophilic methanogenic digester degrading AGS, operated at an HRT of 20 days, in which stable gas production was observed. The seed sludge $(2.4 \mathrm{~L})$ was put into the cathodic working chamber that was then sealed with a top plate, electrodes, sensors, and stainless pipes, and the fermentation broth was thoroughly mixed using a magnetic stirrer. The initial anaerobic condition was established by replacing the gas phase with nitrogen gas. The temperature of the culture was maintained at $55^{\circ} \mathrm{C}$. The operation of the cathodic working chamber was conducted as follows: the predetermined volume of fermentation broth was discharged, and the same amount of fresh AGS was added by using a timer and peristaltic pumps (RP2000, EYELA, Tokyo, Japan). The pH was adjusted to approximately 7.2, with $1.0-\mathrm{N} \mathrm{NaOH}$, throughout the experiment.

The time course for the changes in the HRT and OLR in the cathodic working chamber are summarized in Figure 2. The OLR was increased in a stepwise manner by decreasing the HRT after operation during 3 or more times of HRT. The suspended fractions in the reactors were collected for analysis as the end point for each HRT. In addition, the biomass retained by the working electrode was sampled at day 275 (HRT of 2.0 days). To collect retained biomass, the sample was vigorously vortexed in phosphate-buffered saline, after which any remaining biomass was scraped off.

\section{Analyses of reactor performance}

The gas production rate was measured periodically by water displacement with a graduated cylinder. The $\mathrm{CH}_{4}$, $\mathrm{CO}_{2}$, and $\mathrm{H}_{2}$ contents of the produced gas were measured with a gas chromatograph equipped with a thermal conductivity detector (GC390B, GL Sciences, Tokyo, Japan) and a stainless steel column packed with active carbon (30/60 mesh; GL Sciences). The suspended fractions in the reactors were collected for analyses of physicochemical parameters at approximately 3-day intervals. The CODcr was determined by using the dichromate method with a COD analyzer (DR/800, Hach, Loveland, CO, USA). To determine the total SS, $2-10 \mathrm{~mL}$ of the suspended fraction was passed through the membrane (glass fiber membrane: $0.45 \mu \mathrm{m}, 47 \mathrm{~mm}$; Toyo Roshi Kaisha, Ltd., Tokyo, Japan), after which the membrane was weighed after drying at $105^{\circ} \mathrm{C}$ for $120 \mathrm{~min}$. VFAs (formate, acetate, propionate, and butyrate) were measured using high-pressure liquid chromatography equipped with an organic acid analysis system (TSK-GEL OApak-A and OApak-P, Tosoh, Tokyo, Japan).

\section{DNA extraction and purification}

Biomasses in the suspended fraction and retained on the working electrode of the reactors were centrifuged at $5,000 \times g$, and the resultant pellets were suspended in Tris-EDTA buffer (100-mM Tris- $\mathrm{HCl}$ and 40-mM EDTA, pH 8.0). DNA was extracted from the pellets using repeated bead beating in the presence of sodium dodecyl sulfate and phenol-chloroform-isoamyl alcohol (25:24:1), after which the DNA was purified using a QIAamp DNA Micro Kit (Qiagen, Tokyo, Japan), as described previously (Sasaki et al. 2009).

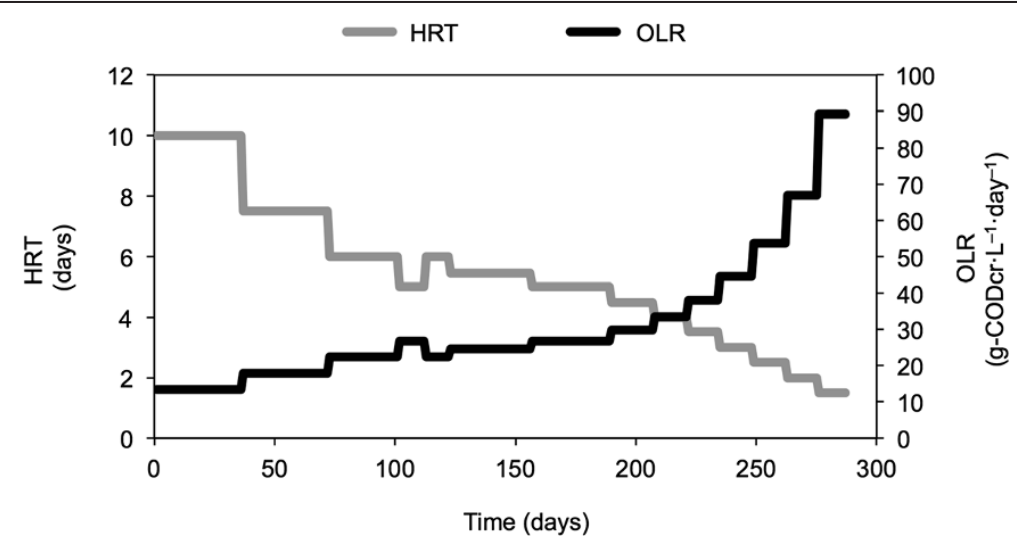

Figure 2 Time courses of HRT (gray line) and OLR (black line) in working chambers of the cathodic BER + CFT. The operation was carried out 285 days from the OLR (HRT) of 13.4 (10 days) to $89.3 \mathrm{~g}$-CODcr $\cdot \mathrm{L}^{-1} \cdot$ day $^{-1}$ (1.5 days). 


\section{Quantitative PCR analysis}

Real-time PCR was performed using a LightCycler 1.5 (Roche Diagnostics, Tokyo, Japan) and LightCycler TaqMan Master (Roche Diagnostics), as previously described (Sasaki et al. 2010a). Primer sets of S-P-MArch0348-S-a-17 and S-D-Arch-0786-A-a-20 were used with the double-dye probe March-0515 for measuring the copy number of $16 \mathrm{~S}$ rRNA from methanogenic archaea (Sawayama et al. 2004). The primer set Uni340F and Uni806R were used with the double-dye probe Uni516F for prokaryotes (Takai and Horikoshi 2000).

\section{T-RFLP analysis}

PCR amplification was performed using AmpliTaqGold (Applied Biosystems, Tokyo, Japan). The primer sets used were Ba27f (Escherichia coli positions 8-27) and Ba907r (E. coli positions 907-926) for the domain Bacteria
(Lueders and Friedrich 2002), or Ar109f (E. coli positions 109-125) and Ar912rt (E. coli positions 912-934) for the domain Archaea (Lueder et al. 2004). T-RFLP analysis was conducted as previously described (Sasaki et al. 2010a).

\section{Results}

Reactor performance in BER + CFT

The mean values of reactor performance at OLRs from 13.4 (HRT of 10 days) to $89.3 \mathrm{~g}$-CODcr $\cdot \mathrm{L}^{-1} \cdot$ day $^{-1}$ (HRT of 1.5 days) are summarized in Figure 3. The gas production rate in the BER + CFT increased as the OLR increased (Figure 3a). The $\mathrm{CH}_{4}$ contents in the produced gas were constant throughout the operation, and the contents of $\mathrm{CH}_{4}$ and $\mathrm{CO}_{2}$ were approximately $60 \%$ and $40 \%$, respectively (data not shown). $\mathrm{H}_{2}$ gas was not detected in the produced gas. Finally, the mean values of the gas production rate (volume of $\mathrm{CH}_{4}$ gas) and $\mathrm{CH}_{4}$

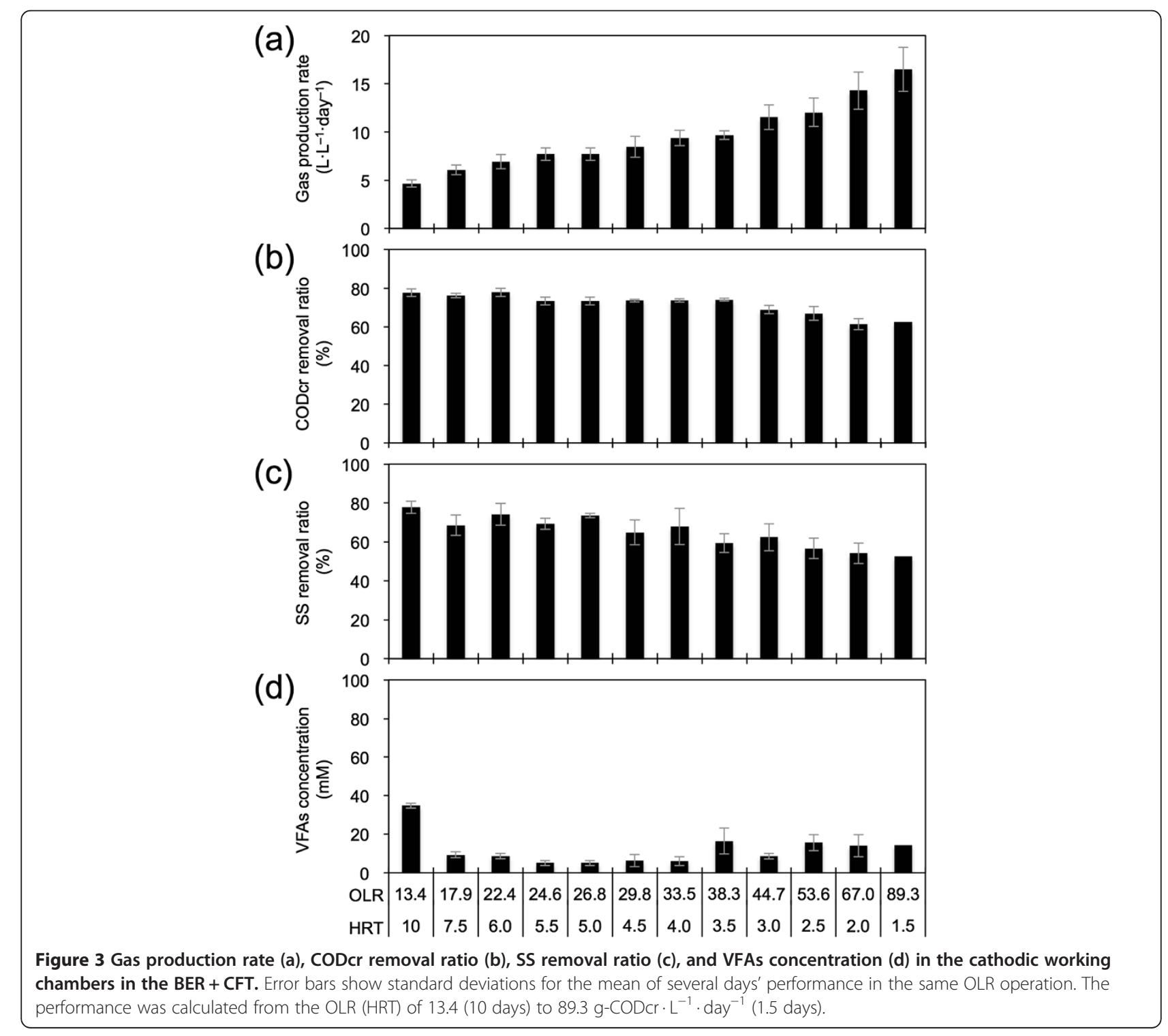


content at $89.3 \mathrm{~g}$-CODcr $\cdot \mathrm{L}^{-1} \cdot$ day $^{-1}$ (HRT of 1.5 days) were $16.5 \mathrm{~L} \cdot \mathrm{L}^{-1} \cdot$ day $^{-1}\left(9.37 \quad \mathrm{~L}-\mathrm{CH}_{4} \cdot \mathrm{L}^{-1} \cdot \mathrm{day}^{-1}\right)$ and $56.8 \%$, respectively, under standard conditions (Table 1). The CODcr and SS removal efficiencies were higher than $60 \%$ (Figure 3b) and 50\%, respectively (Figure 3c), until the end point in the operation. Acetate, propionate, and butyrate were detected as VFAs throughout the operation periods (8.3, 5.0, and $0.9 \mathrm{mM}$ at an OLR of $89.3 \mathrm{~g}$-CODcr . $\mathrm{L}^{-1} \cdot$ day $^{-1}$, respectively). The VFA concentrations were less than $20 \mathrm{mM}$ at all OLRs, except $13.4 \mathrm{~g}$-CODcr $\cdot \mathrm{L}^{-1}$. day $^{-1}$ (Figure 3d).

\section{Diversity of microbial community}

To investigate the bacterial and archaeal community structure, T-RFLP analyses were performed for the suspended fraction (fermentation broth) at several points and for the retained fraction in the CFT at an OLR of $67.0 \mathrm{~g}$-CODcr . $\mathrm{L}^{-1} \cdot$ day $^{-1}$ (Figure 4). From the analysis of bacterial T-RFLP in the suspended fraction, 22 terminal restriction fragments (T-RFs) were detected. A T-RF of $262 \mathrm{bp}$ was dominant throughout the operation period (34.0-79.4\%). In comparison with the bacterial community in the retained fraction with the CFT, no remarkable differences were observed in the suspended fraction and a T-RF of 262 bp was also dominant (41.7\%) in the retained fraction.

In the analysis of archaeal T-RFLP, only 5 of the TRFs $(84,92,186,280$, and $779 \mathrm{bp})$ were detected. T-RFs of 92 and $186 \mathrm{bp}$ were predominant. At an OLR of $67.0 \mathrm{~g}$-CODcr $\cdot \mathrm{L}^{-1} \cdot$ day $^{-1}$, the archaeal T-RFLP profiles were similar between the suspended and retained fractions.

\section{Quantitative analysis of prokaryotes and methanogenic archaea}

Real-time quantitative PCR analysis of the 16S rRNA gene for prokaryotes and methanogenic archaea was conducted in the suspended fraction at several time points of the OLR conditions and the retained fraction to CFT at an OLR of $67.0 \mathrm{~g}$-CODcr $\cdot \mathrm{L}^{-1} \cdot \mathrm{day}^{-1}$ (Table 2). In the suspended fractions, prokaryotic and methanogen copy numbers were $8.7 \times 10^{12}-1.5 \times 10^{13}$ copies $\cdot$ reactor $^{-1}$ and $2.3 \times 10^{12}-4.7 \times 10^{12}$ copies $\cdot$ reactor $^{-1}$, respectively. Ratios of methanogens to prokaryotes in the suspended fraction were $24.2-31.2 \%$ at OLRs from 13.4 to $67.0 \mathrm{~g}$-CODcr. $\mathrm{L}^{-1} \cdot$ day $^{-1}$. However, the ratio of methanogens in the retained fraction to CFT was higher, that is, $52.3 \%$ at an OLR of $67.0 \mathrm{~g}$-CODcr $\cdot \mathrm{L}^{-1} \cdot$ day $^{-1}$. The ratio of methanogens in the retained fraction to those in the total fractions (suspended fraction plus retained fraction) was $27.7 \%$ at an OLR of $67.0 \mathrm{~g}$-CODcr $\cdot \mathrm{L}^{-1} \cdot$ day $^{-1}$.

\section{Discussion}

Utility of the cylindrical BER + CFT

Various methane fermentation systems have so far been examined in the processing of organic garbage wastes
(Table 1). Ueno et al. (2007) operated at quite high OLR, in a thermophilic packed-bed system that packed CFT, and used AGS plus milled paper as substrate, attaining 11.4 $\mathrm{L} \cdot \mathrm{L}^{-1} \cdot$ day $^{-1}$ at an OLR of $53.6 \mathrm{~g}$-CODcr $\cdot \mathrm{L}^{-1}$. day ${ }^{-1}$. By using an OLR of $53.6 \mathrm{~g}$-CODcr $\cdot \mathrm{L}^{-1} \cdot$ day $^{-1}$ in this BER + CFT, the reactor in this study and the packed-bed reactor of Ueno et al. (2007) showed nearly the same values (Table 1). However, the cylindrical BER + CFT in this study could attain $16.5 \mathrm{~L} \cdot \mathrm{L}^{-1} \cdot$ day $^{-1}$ at an OLR of $89.3 \mathrm{~g}$-CODcr $\cdot \mathrm{L}^{-1} \cdot$ day $^{-1}$, which is higher than about $12.5 \mathrm{~L} \cdot \mathrm{L}^{-1} \cdot \mathrm{day}^{-1}$ at an OLR of about $85.0 \mathrm{~g}$-CODcr $\cdot \mathrm{L}$ ${ }^{-1} \cdot$ day $^{-1}$, attained by the packed-bed system of Ueno et al. (2007). Stable reactor performance was observed from 53.6 to $89.3 \mathrm{~g}$-CODcr $\cdot \mathrm{L}^{-1} \cdot$ day $^{-1}$ in the cylindrical $\mathrm{BER}+\mathrm{CFT}$, although the reported packed-bed reactor deteriorated in these OLR conditions. Therefore, the higher OLR operation was achieved using AGS including high percentage of solid fraction in the BER + CFT by introducing a bioelectrochemical system.

\section{Microbial roles in the cylindrical BER + CFT}

From the previous results of T-RFLP and clone analysis (Sasaki et al. 2010b), dominant T-RF of 262 bp had 99\% sequence similarity with the 16S rRNA gene of Defluviitoga tunisiensis (FR850164; Ben Hania et al. 2012). D. tunisiensis belongs to the thermophilic phylum Thermotoga and utilizes many kinds of substrates (e.g., saccharides and cellulose). In the previous results, this T-RF was also dominant in the continuously flow-stirred tank reactor (CFSTR) (Sasaki et al. 2011c) or thermophilic BER degrading AGS (Sasaki et al. 2010b). It has been suggested that the microorganism related to this T-RF is playing an important role in degrading organic materials in garbage wastes (Ben Hania et al. 2012; Sasaki et al. 2011c).

From the previous results of T-RFLP and clone analysis (Sasaki et al. 2010b, 2011b), predominant archaeal T-RFs of 92 and 186 bp were related to the hydrogenotrophic methanogen, Methanothermobacter thermautotrophicus (AY196660; Wasserfallen et al. 2000), and the aceticlastic methanogen, Methanosarcina thermophila (M59140; Rouvière et al. 1992). The remaining T-RFs of 84,280 , and 779 bp were related to the hydrogenotrophic methanogens Methanoculleus thermophilus (EF118904; Spring et al. 2005), Methanothermobacter thermautotrophicus (Wasserfallen et al. 2000), and Methanobacterium formicicum (HQ591420; Sousa et al. 2007), respectively. It has been shown that cathodic reaction by BER increased the growth and methanogenesis of hydrogenotrophic methanogen (Sasaki et al. 2012a; Hirano et al. 2013). Hydrogenotrophic methanogen retained in electron-conductive CFT would be affected by electrochemical regulation. In addition, $M$. thermophila-related microorganisms could become dominant in CFT due to their aggregating nature (Sasaki et al. 2007). From the TRFLP results, the archaeal (methanogenic) community 
Table 1 Reactor performances in thermophilic BER + CFT and previous reactors treating garbage waste under the maximum OLR conditions

\begin{tabular}{|c|c|c|c|c|c|c|c|c|c|c|c|}
\hline & Treating waste & $\begin{array}{l}\text { OLR (g-CODcr. } \\
\left.L^{-1} \cdot \text { day }^{-1}\right)\end{array}$ & $\begin{array}{l}\text { HRT } \\
\text { (days) }\end{array}$ & $\begin{array}{l}\text { CODcr removal } \\
\text { ratio (\%) }\end{array}$ & $\begin{array}{c}\text { VTS } \\
\text { removal } \\
\text { ratio (\%) }\end{array}$ & $\begin{array}{c}\text { SS } \\
\text { removal } \\
\text { ratio (\%) }\end{array}$ & $\begin{array}{l}\text { VSS } \\
\text { removal } \\
\text { ratio (\%) }\end{array}$ & $\begin{array}{l}\text { Gas production } \\
\operatorname{rate}^{a}\left(L \cdot L^{-1} \cdot \text { day }^{-1}\right)\end{array}$ & $\begin{array}{l}\text { Methane } \\
\text { content (\%) }\end{array}$ & $\begin{array}{c}\text { CODcr } \\
\text { recovery }{ }^{\mathbf{b}}(\%)\end{array}$ & References \\
\hline \multirow[t]{2}{*}{ Cylindrical BER + CFT } & \multirow[t]{2}{*}{$10 \%$ AGS } & 89.3 & 1.5 & 62.5 & - & 52.5 & 50.9 & $16.5 \pm 3.4$ & 56.8 & 83.9 & \multirow{2}{*}{$\begin{array}{l}\text { In this } \\
\text { study }\end{array}$} \\
\hline & & 53.6 & 2.5 & $67.0 \pm 3.5$ & - & $56.6 \pm 5.3$ & $51.7 \pm 4.9$ & $12.1 \pm 1.5$ & $58.2 \pm 1.7$ & $117.1 \pm 13.9$ & \\
\hline Packed-bed reactor & $\begin{array}{c}1.5 \% \text { AGS + 1.0\% } \\
\text { milled paper }\end{array}$ & 53.6 & 0.9 & 67.0 & - & - & 67.0 & 11.4 & 60.0 & 56.2 & $\begin{array}{l}\text { Ueno et al. } \\
\text { (2007) }\end{array}$ \\
\hline $\begin{array}{l}\text { Small-scale BER }+ \\
\text { CFT }(-0.8 \mathrm{~V})\end{array}$ & $\begin{array}{l}10 \% \text { AGS + } 0.08 \% \\
\text { ground rice straw }\end{array}$ & 27.8 & 4.4 & $58.0 \pm 4.9$ & - & $38.9 \pm 1.9$ & - & $7.9 \pm 0.7$ & $55.0 \pm 3.2$ & $86.5 \pm 2.6$ & $\begin{array}{l}\text { Sasaki et al. } \\
\text { (2011b) }\end{array}$ \\
\hline CFSTR & $\begin{array}{l}10 \% \text { artificial } \\
\text { kitchen waste }\end{array}$ & 20.4 & 11.0 & 89.0 & & - & - & - & - & 82.0 & $\begin{array}{l}\text { Park et al. } \\
\text { (2008) }\end{array}$ \\
\hline UAF reactor & $\begin{array}{c}\text { Synthetic } \\
\text { garbage }+ \text { swine } \\
\text { manure }\end{array}$ & 17.6 & 9.2 & - & 78.0 & - & - & 8.7 & 50.0 & - & $\begin{array}{l}\text { Liu et al. } \\
\text { (2009) }\end{array}$ \\
\hline CFSTR & $2 \%$ AGS & 6.25 & 4.0 & $65.8 \pm 2.8$ & - & $61.8 \pm 5.6$ & - & $1.8 \pm 0.1$ & 80.0 & - & $\begin{array}{l}\text { Sasaki et al. } \\
\text { (2011c) }\end{array}$ \\
\hline
\end{tabular}

${ }^{\mathrm{a}}$ Mean values under standard temperature and pressure at these OLRs are shown.

${ }^{b} \mathrm{COD} c r$ recovery $=\left[(\mathrm{CODcr}\right.$ of the fermentation broth $)+\left(\mathrm{CODcr}\right.$ of $\left.\left.\mathrm{CH}_{4}\right)\right] /$ Influent $\mathrm{CODcr}$.

VTS: volatile total solid, SS: suspended solid, VSS: volatile suspended solid, UAF reactor: upflow anaerobic filter reactor, CFSTR: continuously flow-stirred tank reactor, AGS: artificial garbage slurry (dog food slurry). 

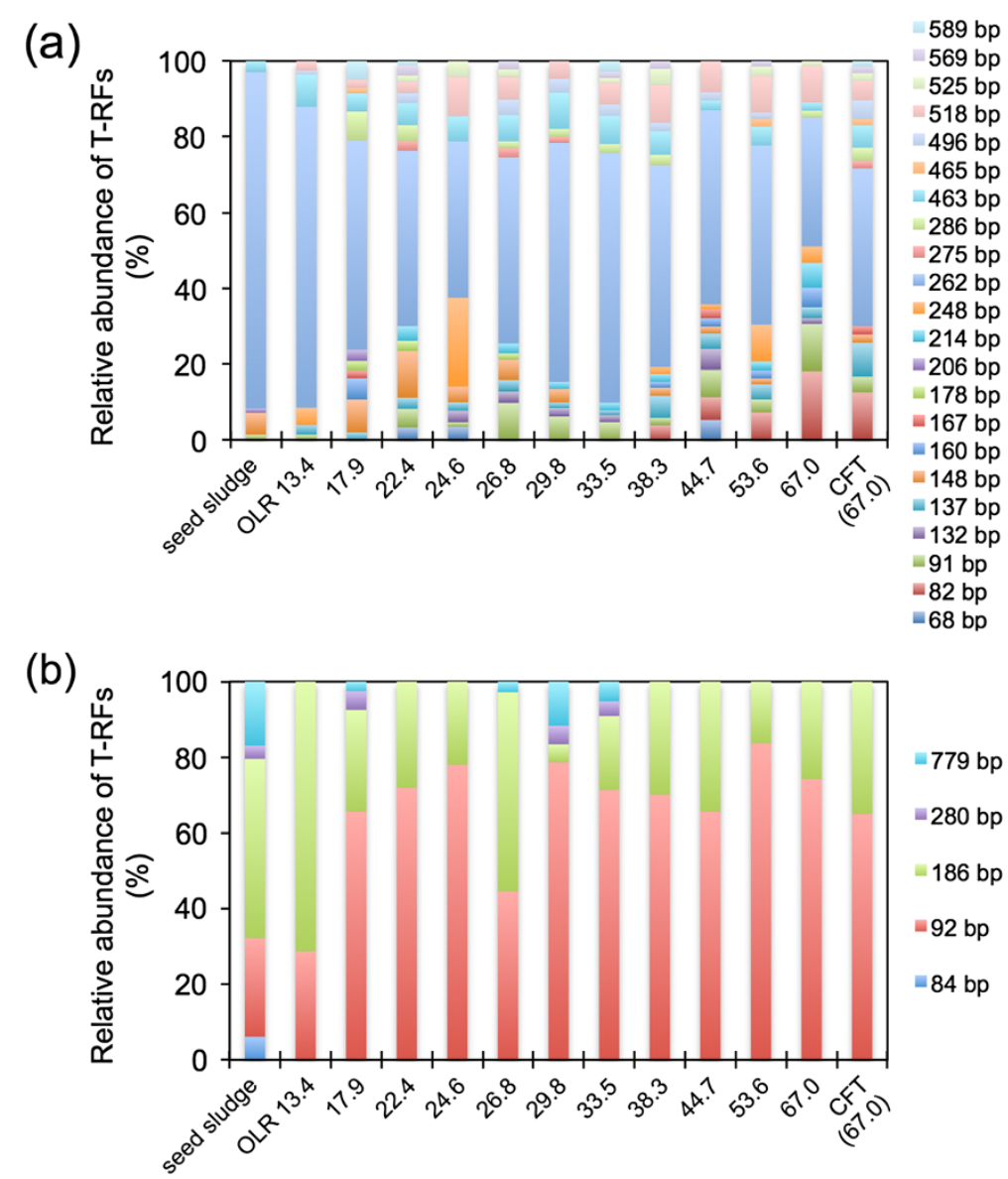

Figure 4 Community dynamics of bacteria (a) and archaea (b), determined by T-RFLP analysis in the BER + CFT. The relative abundances of T-RF generated from DNA samples in the seed sludge, in the suspended fraction at the OLR of 13.4, 17.9, 22.4, 26.8, 29.8, 33.5, 38.3, 44.7, 53.6, and $67.0 \mathrm{~g}-\mathrm{CODCr} \cdot \mathrm{L}^{-1} \cdot \mathrm{day}^{-1}$ and in the retained fraction at the OLR of $67.0 \mathrm{~g}-\mathrm{CODCr} \cdot \mathrm{L}^{-1} \cdot \mathrm{day}^{-1}$.

structure did not show an appreciable succession by changing the OLR conditions through the operating period. Hori et al. (2006) reported that the instability of reactor performance affected the structure of the methanogenic microbial community in the CFSTR, degrading a synthetic substrate after the reactor deteriorated. Therefore, a stable methanogenic community structure would be important for the stable operation of cylindrical BER + CFT under high OLR conditions.

From the results of quantitative analysis of methanogenic archaea, methanogens were highly retained to CFT by attaching directly onto the cathodic electrode, in

Table 2 16S rRNA gene copy numbers of prokaryotes and methanogens in the suspended fraction (OLRs of 13.4, 33.5, $38.0,53.6$, and $67.0 \mathrm{~g}-\mathrm{CODCr} \cdot \mathrm{L}^{-1} \cdot$ day $^{-1}$ ) and retained fraction on the CFT (OLR of $67.0 \mathrm{~g}-\mathrm{CODcr} \cdot \mathrm{L}^{-1} \cdot \mathrm{day}^{-1}$ ) of the BER + CFT

\begin{tabular}{|c|c|c|c|}
\hline OLR $\left(g-C O D c r \cdot L^{-1} \cdot\right.$ day $\left.^{-1}\right)$ & Prokaryotes (copies $\cdot$ reactor $^{-1}$ ) & Methanogens (copies $\cdot$ reactor $^{-1}$ ) & Ratio of methanogens ${ }^{a}(\%)$ \\
\hline \multicolumn{4}{|l|}{ Suspended fraction } \\
\hline 13.4 & $(9.6 \pm 0.4) \times 10^{12}$ & $(2.3 \pm 0.3) \times 10^{12}$ & $24.2 \pm 4.0$ \\
\hline 33.5 & $(8.7 \pm 0.8) \times 10^{12}$ & $(2.6 \pm 0.1) \times 10^{12}$ & $29.6 \pm 3.7$ \\
\hline 38.0 & $(1.3 \pm 0.1) \times 10^{13}$ & $(4.0 \pm 0.5) \times 10^{12}$ & $31.2 \pm 6.7$ \\
\hline 53.6 & $(1.2 \pm 0.2) \times 10^{13}$ & $(3.2 \pm 0.2) \times 10^{12}$ & $27.1 \pm 6.7$ \\
\hline 67.0 & $(1.5 \pm 0.1) \times 10^{13}$ & $(4.7 \pm 0.1) \times 10^{12}$ & $31.2 \pm 2.1$ \\
\hline \multicolumn{4}{|l|}{ Retained fraction } \\
\hline 67.0 & $(3.4 \pm 0.5) \times 10^{12}$ & $(1.8 \pm 0.1) \times 10^{12}$ & $52.3 \pm 9.6$ \\
\hline
\end{tabular}

aProportion of $16 \mathrm{~S}$ rRNA gene copy number of methanogens to that of prokaryotes. 
agreement with previous results (Sasaki et al. 2011b). The ratios of the methanogens in the suspended and retained fractions were comparatively higher than those in the small-scale (250-mL working volume) BER + CFT (ratio of methanogens to prokaryotes in suspended and retained fractions: $15.7-21.3 \%$ and $34.3-36.9 \%$, respectively; Sasaki et al. 2011b). Maintaining methanogens within the reactor would be favorable for operating at high OLR. Also taking into consideration the T-RFLP analysis results, hydrogenotrophic and aceticlastic methanogens could stably grow in CFT. Stable retention of an aceticlastic methanogen would contribute to efficient removal of acetate, thereby preventing acetate accumulation (Sasaki et al. 2007). Hydrogenotrophic methanogens retained in the electron-conductive CFT would work well for hydrogen removal to increase degradation activity of hydrolytic bacteria because syntrophic degradation accelerated the removal of protein or cellulose (Tang et al. 2005; Sasaki et al. 2012a, 2012b).

\section{Current in the cylindrical BER + CFT}

In BER + CFT, the oxidation-reduction potential of the fermentation broth was approximately $-0.45 \mathrm{~V}$ (data not shown). The settled potential $(-0.8 \mathrm{~V})$ was lower than that in the fermentation broth. Therefore, negative current densities were observed in BER + CFT throughout the operation. These results show that the cathodic reaction occurred on the working electrode in the $\mathrm{BER}+\mathrm{CFT}$ regulated at $-0.8 \mathrm{~V}$. The electric current values were nearly similar through the operating period. Here, we discuss the possibility of direct methane production from current reported according to the following reaction (Cheng et al. 2009):

$$
\mathrm{CO}_{2}+8 \mathrm{H}^{+}+8 \mathrm{e}^{-} \rightarrow \mathrm{CH}_{4}+2 \mathrm{H}_{2} \mathrm{O}
$$

Eight electrons (771,882 C, 8 times the Faraday constant) are required to produce $1 \mathrm{~mol}$ of $\mathrm{CH}_{4}$. In the BER+ CFT at $-0.8 \mathrm{~V}$, the mean current density was $-0.21 \mathrm{~A} \cdot \mathrm{m}^{-2}$ at an OLR of $89.3 \mathrm{~g}$-CODcr $\cdot \mathrm{L}^{-1} \cdot$ day $^{-1}$. Therefore, 763.8 $\mathrm{C}\left(8.84 \times 10^{-3} \mathrm{~A} \times 86,400 \mathrm{~s}\right)$ of the mean charges is used in 1 day per the total working electrode $\left(4.2 \times 10^{-2} \mathrm{~m}^{2}\right)$. If all of the current is used to produce $\mathrm{CH}_{4}$, then the current corresponds to only $9.24 \times 10^{-3} \mathrm{~L}_{-} \mathrm{CH}_{4} \cdot \mathrm{L}^{-1} \cdot \mathrm{day}^{-1}$. However, in the BER +CFT, an additional $9.36 \mathrm{~L}-\mathrm{CH}_{4} \cdot \mathrm{L}^{-1}$. day $^{-1}$ was generated $\left[\left(9.37-9.24 \times 10^{-3}\right) \mathrm{L}-\mathrm{CH}_{4} \cdot \mathrm{L}^{-1}\right.$. day $\left.{ }^{-1}\right]$. Therefore, almost all of the $\mathrm{CH}_{4}$ would come from the substrate, suggesting that effects other than direct methane production from the current work for efficient operation of the BER + CFT.

\section{Effectiveness of electric energy}

The input electric energy was compared with the output of the evolved $\mathrm{CH}_{4}$ in the stable operation of the BER $+\mathrm{CFT}$ regulated at $-0.8 \mathrm{~V}$ at an OLR of $89.3 \mathrm{~g}-\mathrm{CODCr} \cdot \mathrm{L}^{-1} \cdot$ day $^{-1}$.
At this OLR (HRT of 1.5 days), absolute values of the mean current densities and voltages between the working electrode and counter electrode were $0.21 \mathrm{~A} \cdot \mathrm{m}^{-2}$ and $1.88 \mathrm{~V}$. As a result, $16.6 \mathrm{~mW} \cdot$ reactor $^{-1} \cdot$ day $^{-1}\left(0.6 \mathrm{~kJ} \cdot \mathrm{L}^{-1} \cdot\right.$ day $\left.^{-1}\right)$ of the input energies were consumed per total CFT $(4.2 \times$ $10^{-2} \mathrm{~m}^{2}$ ). The mean value of $\mathrm{CH}_{4}$ gas was $9.37 \mathrm{~L}_{-} \mathrm{CH}_{4}$. $\mathrm{L}^{-1} \cdot$ day $^{-1}$, and from the reaction enthalpy $\left(\Delta \mathrm{r} H^{o}\right)$ for the combustion of $\mathrm{CH}_{4}$ gas, which is $-890.71 \mathrm{~kJ} \cdot \mathrm{mol}^{-1}$ under standard conditions (Dean 1999), $\mathrm{CH}_{4}$ production corresponded to $372.6 \mathrm{~kJ} \cdot \mathrm{L}^{-1} \cdot$ day $^{-1}\left[\left(9.37 \mathrm{~L}-\mathrm{CH}_{4} \cdot \mathrm{L}^{-1}\right.\right.$. day $\left.\left.^{-1} / 22.4 \mathrm{~L}\right) \times 890.71 \mathrm{~kJ} \cdot \mathrm{mol}^{-1}\right]$. It was revealed that much higher output energy as $\mathrm{CH}_{4}$ was produced than input energies.

It has been predicted that electric input energy is used to control the redox potential in the fermentation broth, which is optimal for a complex microbial community that includes bacteria and/or methanogens. A syntrophic relationship between bacteria and methanogens was often reported in methanogenic microbial communities (Stams and Plugge 2009; Sasaki et al. 2012b). To understand the effect of the electrochemical reaction on the microbial relationship, information on the isolated microorganisms would be required from now on. We succeeded in stably operating the scaled-up cylindrical BER + CFT to treat the model garbage waste at high OLR. The scaled-up cylindrical BER + CFT can be utilized for construction of sustainable society recycling of municipal solid wastes.

\section{Competing interests}

The authors declare that they have no competing interests.

\section{Acknowledgments}

We thank Akiko Matsumoto, Mieko Katsuura, Yumi Kotake, Naho Kitazawa, Chikako Nakayama, and Yukie Tomita for their analytical support in the experiments. This work was supported by the New Energy and Industrial Technology Development Organization (NEDO), Japan.

\section{Author details}

${ }^{1}$ Biotechnology Sector, Environmental Science Research Laboratory, Central Research Institute of Electric Power Industry, 1646 Abiko, Abiko-shi,

Chiba-ken 270-1194, Japan. ${ }^{2}$ Department of Biotechnology, Graduate School of Agricultural and Life Sciences, The University of Tokyo, Yayoi 1-1-1, Bunkyo-ku, Tokyo 113-8657, Japan. ${ }^{3}$ Present address: Graduate School of Engineering, Kobe University, 1-1 Rokkodai-cho, Nada-ku, Kobe, Hyogo 657-8501, Japan.

Received: 17 January 2013 Accepted: 1 March 2013

Published: 13 March 2013

\section{References}

Ahring BK (2003) Perspectives for anaerobic digestion. Adv Biochem Eng Biotechnol 81:1-30

Angenent LT, Sung S, Raskin L (2002) Methanogenic population dynamics during startup of a full-scale anaerobic sequencing batch reactor treating swine waste. Water Res 36:4648-4654

Ben Hania W, Godbane R, Postec A, Hamdi M, Ollivier B, Fardeau ML (2012) Isolation and characterization of Defluviitoga tunisiensis gen. nov, sp. nov., a novel thermophilic bacterium pertaining to the order Thermotogales, isolated from a mesothermic anaerobic reactor treating cheese whey in Tunisia. Int J Syst Evol Microbiol 62:1377-1382

Cheng S, Xing D, Call DF, Logan BE (2009) Direct biological conversion of electrical current into methane by electromethanogenesis. Environ Sci Technol 43:3953-3958 
Dean JA (1999) Lange's Handbook of Chemistry, 15th edn. McGraw-Hill Inc, New York, NY

Forster-Carneiro T, Pérez M, Romero LI (2008) Thermophilic anaerobic digestion of source-sorted organic fraction of municipal solid waste. Bioresour Technol 99:6763-6770

Haruta S, Nakamura T, Nakamura K, Hemmi H, Ishii M, Igarashi Y, Nishino T (2005) Microbial diversity in biodegradation and reutilization processes of garbage. $J$ Biosci Bioeng 99:1-11

Hirano SI, Matsumoto N, Morita M, Sasaki K, Ohmura N (2013) Electrochemical control of redox potential affects methanogenesis of the hydrogenotrophic methanogen Methanothermobacter thermautotrophicus. Lett Appl Microbiol: doi:10.1111/lam.12059, in press

Hori T, Haruta S, Ueno Y, Ishii M, Igarashi Y (2006) Dynamic transition of a methanogenic population in response to the concentration of volatile fatty acids in a thermophilic anaerobic digester. App Environ Microbiol 72:1623-1630

Liu K, Tang YQ, Matsui T, Morimura S, Wu XL, Kida K (2009) Thermophilic anaerobic co-digestion of garbage, screened swine, and dairy cattle manure. J Biosci Bioeng 107:54-60

Lueders T, Friedrich MW (2002) Effects of amendment with ferrihydrite and gypsum on the structure and activity of methanogenic populations in rice field soil. Appl Environ Microbiol 68:2484-2494

Lueders T, Manefield M, Friedrich MW (2004) Enhanced sensitivity of DNA- and rRNA-based stable isotope probing by fractionation and quantitative analysis of isopycnic centrifugation gradients. Environ Microbiol 6:73-78

Matsumoto N, Yoshinaga H, Ohmura N, Ando A, Saiki H (2002) Numerical simulation for electrochemical cultivation of iron oxidizing bacteria. Biotechnol Bioeng 78:17-23

Park Y, Hong F, Cheon J, Hidaka T, Tsuno H (2008) Comparison of thermophilic anaerobic digestion characteristics between single-phase and two-phase systems for kitchen garbage treatment. J Biosci Bioeng 105:48-54

Rouvière P, Mandelco L, Winker S, Woese CR (1992) A detailed phylogeny for the Methanomicrobiales. Syst Appl Microbiol 15:363-371

Sasaki K, Haruta S, Ueno Y, Masaharu I, Igarashi Y (2007) Microbial population in the biomass adhering to supporting material in a packed-bed reactor degrading organic solid waste. Appl Microbiol Biotechnol 75:941-952

Sasaki K, Morita M, Hirano S, Ohmura N, Igarashi Y (2009) Effect of adding carbon fiber textiles to methanogenic bioreactors used to treat an artificial garbage slurry. J Biosci Bioeng 108:130-135

Sasaki K, Sasaki D, Morita M, Hirano S, Matsumoto N, Ohmura N, Igarashi Y (2010a) Efficient treatment of garbage slurry in methanogenic bioreactor packed by fibrous sponge with high porosity. Appl Microbiol Biotechnol 86:1573-1583

Sasaki K, Sasaki D, Morita M, Hirano S, Matsumoto N, Ohmura N, Igarashi Y (2010b) Bioelectrochemical system stabilizes methane fermentation from garbage slurry. Bioresour Technol 101:3415-3422

Sasaki K, Hirano S, Morita M, Sasaki D, Matsumoto N, Ohmura N, Igarashi Y (2011a) Bioelectrochemical system accelerates microbial growth and degradation of filter paper. Appl Microbiol Biotechnol 89:449-455

Sasaki K, Morita M, Sasaki D, Hirano S, Matsumoto N, Watanabe A, Ohmura N, Igarashi Y (2011b) A bioelectrochemical reactor containing carbon fiber textiles enables efficient methane fermentation from garbage slurry. Bioresour Technol 102:6837-6842

Sasaki D, Hori T, Haruta S, Ueno Y, Ishii M, Igarashi Y (2011c) Methanogenic pathway and community structure in a thermophilic anaerobic digestion process of organic solid waste. J Biosci Bioeng 111:41-46

Sasaki D, Sasaki K, Morita M, Hirano S, Matsumoto N, Ohmura N (2012a) Bioelectrochemical regulation accelerates facultatively syntrophic proteolysis. J Biosci Bioeng 114:59-63

Sasaki D, Morita M, Sasaki K, Watanabe A, Ohmura N (2012b) Acceleration of cellulose degradation and shift of product via methanogenic co-culture of a cellulolytic bacterium with a hydrogenotrophic methanogen. J Biosci Bioeng 114:435-439

Sasaki D, Sasaki K, Watanabe A, Morita M, Igarashi Y, Ohmura N (2013) Operation of a cylindrical bioelectrochemical reactor containing carbon fiber fabric for efficient methane fermentation from thickened sewage sludge. Bioresour Technol 129:366-373

Sawayama S, Tada C, Tsukahara K, Yagishita T (2004) Effect of ammonium addition on methanogenic community in a fluidized bed anaerobic digestion. J Biosci Bioeng 97:65-70
Sousa DZ, Smidt H, Alves MM, Stams AJ (2007) Syntrophomonas zehnderi sp. nov., an anaerobe that degrades long-chain fatty acids in co-culture with Methanobacterium formicicum. Int J Syst Evol Microbiol 57:609-615

Spring S, Schumann P, Spröer C (2005) Methanogenium frittonii Harris et al. 1996 is a later synonym of Methanoculleus thermophilus (Rivard and Smith 1982) Maestrojuan et al. 1990. Int J Syst Evol Microbiol 55:1097-1099

Stams AJM, Plugge CM (2009) Electron transfer in syntrophic communities of anaerobic bacteria and archaea. Nat Rev Microbiol 7:568-577

Takai K, Horikoshi K (2000) Rapid detection and quantification of members of the archaeal community by quantitative PCR using fluorogenic probes. Appl Environ Microbiol 66:5066-5072

Tang Y, Shigematsu T, Morimura S, Kida K (2005) Microbial community analysis of mesophilic anaerobic protein degradation process using bovine serum albumin (BSA)-fed continuous cultivation. J Biosci Bioeng 99:150-164

Tatara M, Makiuchi T, Ueno Y, Goto M, Sode K (2008) Methanogenesis from acetate and propionate by thermophilic down-flow anaerobic packed-bed reactor. Bioresour Technol 99:4786-4795

Thrash JC, Van Trump JI, Weber KA, Miller E, Achenbach LA, Coates JD (2007) Electrochemical stimulation of microbial perchlorate reduction. Environ Sci Technol 41:1740-1746

Ueno Y, Tatara M, Fukui H, Makiuchi T, Goto M, Sode K (2007) Production of hydrogen and methane from organic solid wastes by phase-separation of anaerobic process. Bioresour Technol 98:1861-1865

Wasserfallen A, Nölling J, Pfister P, Reeve J, Conway de Macario E (2000) Phylogenetic analysis of 18 thermophilic Methanobacterium isolates supports the proposals to create a new genus, Methanothermobacter gen. nov., and to reclassify several isolates in three species, Methanothermobacter thermautotrophicus comb. nov., Methanothermobacter wolfeii comb. nov., and Methanothermobacter marburgensis sp. nov. Int J Syst Evol Microbiol 50:43-53

doi:10.1186/2191-0855-3-17

Cite this article as: Sasaki et al.: Efficient production of methane from artificial garbage waste by a cylindrical bioelectrochemical reactor containing carbon fiber textiles. AMB Express 2013 3:17.

\section{Submit your manuscript to a SpringerOpen ${ }^{\circ}$ journal and benefit from:}

- Convenient online submission

- Rigorous peer review

- Immediate publication on acceptance

- Open access: articles freely available online

- High visibility within the field

- Retaining the copyright to your article

Submit your next manuscript at $>$ springeropen.com 